\title{
PENDEKATAN SOSIO-HISTORIS: Alternatif dalam Memahami Perkembangan Ilmu Kalam
}

\author{
Nurul Djazimah \\ Jurusan Perbandingan Agama Fakultas Ushuluddin IAIN Antasari Banjarmasin \\ Jl. A. Yani Km. 4,5 Banjarmasin
}

Diterima 22 Oktober 2011/Disetujui 15 Nopember 2011

\begin{abstract}
This paper studies about the developing of ilm kalam. As for the writer, there are many historical events that colored the muslim's thought in field of ushuluddin. The status of islamic theology (faith) in the period of the Prophet and his companions were very different with the mutakkilimin's thought in next century. The expression and the discussion and the argumentations were submitted is really different between prophetic period and mutakklimin one. Even, in the body of mutakkalimin its self there are several models in expression and argumentation. This reality was caused by many factors and conditions. By seeing the developing of ilm ushuluddin time by time, can be concluded that the thought of intelectual muslim in last time was relevant with the challange in that time. It means that in our period today where the the science and the technology evolved rapidly, needed the new model of ilm taubid that relevant with the situation and the condition today. So that, the world of God (ayat kauniyyah) that we may find in many verses in Alquran must be learned in particular.
\end{abstract}

Kata kunci: ilmu kalam, sosio-historis, periode Mubammad

\section{Pendahuluan}

Islam datang untuk mengajarkan kebenaran dan keselamatan manusia. Ajaran yang termaktub dalam Alquran dan Hadis adalah sebagai das sollen yang harus diyakini kebenarannya, baik yang menyangkut akidah maupun yang menyangkut syariat.

Islam dari awal kelahirannya sampai masa perkembangannya di masa sekarang tidak lepas dari masyarakat yang berbudaya. Hal ini tidak dapat dimungkiri apabila kita melihat sepanjang sejarah pemikiran umat Islam dalam memahami agama. Dalam bidang syari'at (fikih) misalnya; Abu 
Hanifah (mazhab Hanafi) dikenal dengan abl al-ra'y (lebih banyak dalam menentukan hukum fikih). Sikap ini dapat dimengerti, karena Imam Abu Hanifah menetap di Kufah yang jauh dari pusat perkembangan agama Islam dan sedikit sekali sahabat yang pernah tinggal di sana. Faktor inilah yang memaksa beliau harus banyak mempergunakan penalaran dalam mengungkapkan pendapatnya. Sebaliknya Imam Malik (mazhab Maliki) dikenal sebagai abl al-hadîts (lebih banyak mempergunakan hadis dalam menentukan hukum-hukumnya). Sikap ini dapat dipahami, karena Imam Malik menetap di Madinah yang sebagian besar sahabat Nabi tinggal dan menyampaikan hadis-hadis.

Demikian pula hal adanya dua pendapat dari Imam al-Syafi'i tentang suatu masalah. Di satu pihak belah dikenal sebagai qawl qadim (pendapat lama), di lain pihak beliau dikenal dengan qawl jadìd (pendapat baru).

Dari kenyataan tersebut di atas dapat dipahami bahwa pemikiran keagamaan itu tidak bisa lepas dari perkembangan sejarah dan budaya serta tidak bisa melepaskan diri dari pengaruh faktor situasional dan kondisional, baik berupa faktor tempat ataupun waktu.

Dalam perkembangan Ilmu Ushuluddin di kalangan umat Islam, di situ dapat diperhatikan serentetan sejarah yang mewarnai pemikiran umat Islam dalam bidang Ilmu Ushuluddin. Keadaan Ilmu Ushuluddin (akidah) di jaman Nabi saw. dan sahabat sangat berbeda coraknya dengan pemikiran mutakallimin di abad kemudian. Pengungkapan, pembahasan serta argumentasi-argumentasi yang diajukan sangat berbeda antara jaman Rasulullah dengan jaman mutakallimin. Bahkan di kalangan mutakallimin sendiri didapati perbedaan model pengungkapannya maupun perbedaan pendapat. Kenyataan ini pun disebabkan pengaruh berbagai faktor situasional dan kondisional.

Jika kita ingin mengeksplarasi suatu agama, maka tidak lepas dari dua dimensi., yaitu dimensi historis dan normatif. Dalam dimensi normatif manusia akan mengakui adanya sesuatu yang transendental mutlak dan universal. Inilah realitas ketuhanan. Namun dari segi historis, perkembangan agama tidak lepas dari unsur penganutnya yang berhak dalam ruang dan waktu. Agama dalam konteks ini terangkai oleh kehidupan pemeluknya. Karenanya pemahaman manusia terhadap yang transendental tidak akan 
pernah sama persis seperti yang dikehendaki-Nya. Inilah realitas ketuhanan dan kemanusiaan. ${ }^{1}$

Dalam kaitannya dengan pendekatan historis, pada hakikatnya menurut sejarah adalah respons orisinal dari kesadaran personal yang mampu mempengaruhi kondisi sosial dan kehidupan. ${ }^{2}$ Para teologi pun sependapat dengan hal ini.

Berdasarkan pemikiran di atas makalah ini dimaksudkan untuk mengungkap bahwa Sejarah Kebudayaan Islam (SKI) yang merupakan bagian dari socio-history dapat dijadikan sebagai alat yang berusaha untuk memahami ajaran Islam dengan memperhatikan (socio cultural) dimana ia tumbuh dan berkembang. Lebih khusus lagi bahwa untuk memahami Ilmu Ushuluddin di sepanjang sejarah sangat diperlukan pendekatan socio-history. Lebih jauh lagi diharapkan dapat memberi kesan bahwa di masa kini misalnya tidak tertutup adanya kemungkinan untuk menciptakan model baru dalam memahami masalah ketuhanan sesuai dengan kondisi dan situasi dimana ilmu pengetahuan dan teknologi sedangan berkembang begitu maju.

\section{Pendekatan Sosio Historis}

Kehidupan agama di tengah-tengah masyarakat tak berbeda dengan kehidupan makhluk hidup pada suatu daerah tertentu. Untuk memahami agama di samping mengetahui sejauh mana das sollen itu mempengaruhi masyarakat beragama, juga melalui pemahaman sejauh mana perkembangan budaya itu mempengaruhi penghayatan terhadap das sollen.

Keadaan kondisional dan situasional pada masyarakat tertentu sangat mempengaruhi pertumbuhan dan perkembangan kehidupan suatu agama. Setiap perubahan dan perkembangan dalam bidang sosial, politik, ekonomi dan kebudayaan pada umumnya merupakan faktor yang sangat mempengaruhi kehidupan beragama. Oleh karena itu tingkah laku dan alam pikiran keagamaan seseorang individu dan masyarakat beragama tidak bisa

\footnotetext{
${ }^{1}$ Gregory Baum, Agama dalam Bayang-bayang Relativisme (Yogyakarta: Tiara Wacana, 1999), h. $\mathrm{xx}$.

${ }^{2}$ Hilman Hadi Kusumo, Antropologi Agama Bagian I (Bandung: PT. Citra Aditiya Bakdi, 1993), h. 11.
} 
diterangkan dan dimengerti lepas dari ikatan pengaruh atau faktor-faktor tersebut.

Oleh karena itu pendekatan historis dalam perkembangan agama juga menggunakan pendekatan relativisme dan relasituisme. Artinya bahwa semua pendekatan sosial tidak bisa berdiri sendiri dan dibatasi oleh lokasi pemikiran dan alasan-alasannya yang tidak bisa dihindari dari semua kebenaran manusia (buman truth). ${ }^{3}$

Dalam kaitannya dengan masalah ini Sayyed Husen Allatas berpendapat bahwa dengan metode sicio historis sebagai pemahaman berarti bahwa setiap agama, buah pikiran orang atau masyarakat, harus dilihat, sebagai suatu kenyataan yang mempunyai kesatuan dengan waktu, tempat, kebudayaan, golongan dan lingkungan dimana kepercayaan, ajaran dan kejadian itu timbul. Dengan kata lain perubahan corak pemikiran keagamaan tidak bisa lepas dari perubahan sosial budaya setempat. ${ }^{4}$

Dalam kenyataan sejarah cukup banyak usaha yang dilakukan oleh pemikir-pemikir agama dalam memahami ajaran agama dari sumber pokoknya. Hasil pemikiran tokoh-tokoh agama itu telah menghasilkan ajaran-ajaran agama yang diperpegangi oleh masyarakat beragama. Dalam bidang akidah misalnya, terdapat perbedaan antara beberapa paham atau aliran (khalaf dan salaf). Dalam khalaf sendiri berkembang beberapa aliran seperti aliran Asy'ari, aliran Mu'tazilah dan sebagainya. Hal ini bisa terjadi dikarenakan di dalam agama seseorang dapat memahami ajaran agama melalui pemikirannya, penafsiran terhadap ajaran agama. Semua pemikiran yang mereka sumbangkan itu tidak lain adalah merupakan sumbangan besar untuk menjawab tantangan jaman.

Dengan tidak mengesampingkan apa yang telah dicapai oleh tokohtokoh/pemikir agama di masa silam dengan cara dan kemampuannya serta telah diperpegangi oleh pengikutnya, masih dirasakan adanya suatu metode pemahaman ajaran yaitu metode sosio-historis. Metode ini dimaksudkan untuk memahami dan mendekati firman Tuhan dan sabda Nabi yang meliputi prinsip-prinsip sosial, politik, ekonomi, pendidikan, hukum, dan

\footnotetext{
${ }^{3}$ Gregori Baunu, Agama dalam, h. 7.

${ }^{4}$ Karl Manhein, Ideology and Utopia (Havert Book) (New York: Haurecaunt Brace \& Word, 1936), h. 78-79.
} 
kepercayaan dan sebagainya dengan memperhatikan konteks waktu, tempat dan kebudayaan setempat, dimana agama itu disampaikan atau dimana aliran itu ditimbulkan.

Metode sosio-historis ini merupakan proses pemikiran yang terpadu antara das sollen dan das sein, dalam usaha memahami wahyu atau suatu aliran dengan berpijak di atas realitas sekeliling manusia. Berpikir dengan cara demikian berarti suatu usaha untuk memahami agama dengan menarik ke alam kenyataan. Tanpa pengetahuan tentang masyarakat, sejarah dan kebudayaan sesuatu agama sebelum dan sesudah lahirnya, maka agama itu sulit dimengerti dengan baik. Demikian pula pengetahuan tentang masyarakat, sejarah dan kebudayaan setempat dimana agama itu tersiar dan berkembang perlu mendapat perhatian apabila ingin mengerti agama itu.

Seseorang sosiolog bernama Scheler berpendapat bahwa pikiran logis sekalipun dibentuk secara historis, karena itu secara sadar atau tidak ia merefleksikan kebudayaannya sendiri. Dalam banyak hal setiap masyarakat dan kebudayaannya merupakan sebuah totalitas yang diproduksi oleh historis.

Dari segi lain dapat dimengerti bahwa pemahaman agama ialah penghayatan agama. Pemahaman ini sudah barang tentu berlangsung di dalam suatu masyarakat tertentu. Sedangkan masyarakat mempunyai hubungan dinamis timbal balik dengan pribadi. Dengan demikian masyarakat dengan nilai-nilainya akan mempengaruhi pribadi/orang dalam beragama. Di sinilah metode sosio-historis akan dijadikan sebagai alat untuk mengetahui, mengutarakan, merumuskan agama sebagai bentuk pemikiran, tingkah laku dan perwujudan agama pada suatu waktu dan tempat. Suatu pergeseran aksentuasi. Ini disebabkan dalam hal penghayatan agama dan perwujudan agama pemikiran agama bertitik tolak dari situasi konkret atau pada pengalaman manusia beragama untuk memproduksi ulang keyakinan-keyakinan agama. Karena itu pemahaman ajaran agama dalam setiap lingkungan budaya dan kurun waktu tidak akan mengalami perubahan.

Dengan mempelajari Sejarah Kebudayaan Islam, di situ akan dapat dilihat gambaran situasi konkret (sosial-budaya) yang melilit jamannya. Di masa Rasulullah, masa sahabat, masa Daulah Bani Umayyah, masa Daulah Bani Abbasyiah dan seterusnya, masing-masing jaman itu mempunyai corak 
dan sosial-budaya yang berbeda satu sama lain.

Sedangkan perkembangan pemikiran itu pada hakikatnya tidak bisa lepas dari perubahan masyarakat itu sendiri. Oleh karena itu mempelajari Sejarah Kebudayaan Islam dari masa ke masa sangat membantu untuk memahami Ilmu Ushuluddin dan pertumbuhannya.

Jadi yang dimaksud Sejarah Kebudayaan Islam sebagai alat pendekat sosio-historis dalam Ilmu Ushuluddin adalah dengan mempelajari Sejarah Kebudayaan Islam seseorang akan memperoleh pemahaman bahwa setiap aliran paham, gagasan atau gejala itu mempunyai kesatuan mutlak dengan waktu, tempat, kebudayaan, golongan, lingkungan dan sebagainya dimana ia lahir.

\section{Perkembangan Ilmu Ushuluddin}

\section{Masa Rasulullah}

Masalah akidah/Ketuhanan di masa Rasulullah masih dalam bentuk yang sederhana dan murni. Persoalan akidah tidak keluar dari ketentuan pokok yang sudah digariskan dalam Alquran dan Hadis. Pada masa ini tidak ada pertentangan pendapat di antara kaum Muslimin tentang sifatsifat Tuhan dan kedudukan sifat tersebut apakah ia sifat zat atau sifat fi'il. Mereka hanya meyakini bahwa sifat-sifat Allah ini azali. ${ }^{5}$

Masalah akidah di masa Rasulullah ini cukup sederhana, tidak terlalu ruwet masalahnya di mana akal harus memperdebatkannya. Misalnya dalam masalah kadar, diriwayatkan bahwa Rasulullah saw. suatu saat berjalanjalan menemui sahabat-sahabatnya, dan kebetulan saat itu mereka sedang memperdebatkan tentang masalah kadar. Terdengar seorang laki-laki berkata tidaklah Allah berkata demikian. Maka Rasulullah saw. marah sambil berkata apakah dengan demikian kamu disuruh. Sesungguhnya telah benar orang-orang dahulu karena bertengkar seperti ini. Mereka menjadikan kitab Allah itu menyalahkan setengahnya akan setengah yang lain. Hanya kitab Allah itu diturunkannya adalah untuk membenarkannya setengah akan setengahnya bukan menyalahkannya. Perhatikanlah apa-apa

${ }^{5}$ M. T.T. Abdul Muin, Ilmu Kalam (Jakarta: Wijaya, 1973), h. 16. 
yang disuruh kepadamu perbuatlah dan apa-apa yang dilarang kepadamu jauhilah. ${ }^{6}$

\section{Masa Khulafaurrasyidin}

Pada dasarnya masalah akidah di masa Khulafaurrasyidin tidak jauh berbeda dengan masa Rasulullah. Para Khalifah selalu menjaga akidah keimanan sebagaimana yang diajarkan oleh Rasulullah dan melaksanakan apa yang diperintahkan Allah serta menjauhi semua yang dilarangnya. Mereka juga berusaha tidak mempertentangkan masalah-masalah akidah. Sama halnya dalam masalah kadar yang pernah disebut-sebut di masa Rasulullah saw. Khalifah Umar r.a. juga bertindak sebagaimana tindakan Rasulullah. Diriwayatkan bahwa Umar r.a. mendatangkan seorang pencuri? Pencuri menjawab; telah ditetapkan kadar atasku. Maka Umar r.a. pun menyuruh potong tangan atas pencuri dan didera beberapa kali. Maka Sayyidina Umar r.a. ditanya, Umar r.a. menjawab hukuman potongan tangan itu karena ia mencuri dan hukuman dera itu karena ia berdusta atas nama Allah. Persoalan tersebut dapat dipahami bahwa Umar r.a. tidak ingin memperdebatkan masalah kadar itu dengan pemahaman akan yang bisa menimbulkan salah pengertian dan perpecahan di kalangan umat.

Dengan terbunuhnya Khalifah Utsman bin 'Affan, disusul dengan baiat Ali bin Abu Thalib yang hanya disetujui oleh penduduk Madinah saja, diiringi dengan pertempuran-pertempuran di kalangan umat Islam yang mengakibatkan timbul kekacauan politik, yang akhirnya menjurus pembentukan suatu aliran/paham di kemudian hari. Masalah Imamah dan syarat-syaratnya menjadi topik pembicaraan setelah terjadinya peristiwa khalifah Utsman terbunuh. Lebih lanjut dihubungkan dengan masalah siapa yang melakukan pembunuhan itu. Di sini timbul bibit paham Qadariyah dan Jabariyah. ${ }^{7}$

\section{Masa Bani Umayyah}

Akibat dari kekacauan politik pada masa Khalifah Ustman bin 'Affan dan Ali, timbul beberapa golongan dalam Islam, yaitu golongan Khawarij, Syi'ah dan Murji'ah. Golongan ini pada mulanya tumbuh disebabkan ada

${ }^{6}$ Ali Mustafa al-Garaby, Tarikh al-Firaq al-Islamiy (t.tp.: Azhar, t.th.), h. 13.

${ }^{7}$ Al-Garaby, Tarikh al-Firaq, h. 15. 
unsur politik, namun pada kelanjutannya berkembang menjadi aliran keagamaan. Hal ini terjadi disebabkan masing-masing berusaha untuk memperkuat pendirian-pendirian politik mereka dengan menggunakan dalih agama yang bisa menguntungkan politik mereka. ${ }^{8}$ Golongan Khawarij mengafirkan yang lain. Golongan Syi'ah mengkufurkan orang yang berbuat dosa besar, dan mempercayai seorang imam termasuk rukun iman. Bagi golongan Murji'ah siapa beriman kepada Allah dan Rasul-rasul-Nya sudah termasuk mukmin, meskipun dia berbuat dosa besar. Bahkan ada di kalangan Murji'ah yang berpendapat iman adalah kepercayaan dalam hati, meskipun lisannya mengatakan kekafiran. ${ }^{9}$ Kemudian timbul pendapat yang lain dan berpendapat bahwa orang yang melakukan dosa besar bukanlah kafir dan bukan pula mukmin. Pendapat ini dipelopori oleh Washil bin 'Atha yang kemudian menjadi aliran Muktazilah. ${ }^{10}$ Pada masa ini perbincangan masalah qadar dan masalah istith'ah yang dipelopori oleh Ma'bad al-Juhani cs. (Qadariyah). Di lain pihak ada yang meniadakan kudrat dan iradat manusia yang ditokohi oleh Jaham bin Safwan (Jabariyah). ${ }^{11}$

4. Masa Bani Abbasyiah

Di masa ini masalah akidah Islam lebih kompleks persoalannya. Masalahnya lebih menjadi rumit apabila dibandingkan dengan masa Rasulullah dan Khulafaurrasyidin. Argumentasi-argumentasi yang digunakan untuk mengiktikadkan wujud Tuhan dan ke-Esaan-Nya sangat berbeda dengan jaman-jaman sebelumnya. Demikian pula masalah zat dan sifat serta qadha dan qadar di jaman Rasulullah dan Khalifaturrasyidin tidak diperbincangkan, akan tetapi pada masa ini masalah tersebut benar-benar menjadi obyek persoalan. Di samping masalah itu juga masalah "sifat aktif", "sifat ilmu", "sifat kalam", kejasmanian", "arbam", “ru'yab”, dan keadilan Tuhan menjadi objek pembicaraan di antara mutakallimin.

Tokoh-tokoh mutakallimin yang dikenal di masa ini antara lain Washil bin Atha (pendiri aliran Muktazilah), Imam Asy'ari (pendiri aliran

${ }^{8}$ Ahmad Amin, Fajr al-Islam, terj. Zaini Dahlan (Jakarta: Bulan Bintang, 1968), h. 357.

${ }^{9}$ Ahmad Amin, Fajr al-Islam, h. 360.

${ }^{10}$ Harun Nasution, Islam Ditinjau dari Beberapa Aspek (Jakarta: Bulan Bintang, 1974), h. $36-37$.

${ }^{11}$ Hasby ash-Shiddieqy, Sejarah Pengantar Ilmu Taubid (Jakarta: Bulan Bintang, 1979), h. 19. 
Asy'ariyah), dan Maturidy (pendiri aliran Maturidiyah). Modos pemikiran dan argumentasi digunakan oleh mutakallimin (Muktazilah, Asy'ariyah, dan Maturidiyah) dalam masalah "wujud Tuhan" (mengiktikadkan dan mengesakan Allah) masing-masing menggunakan argumentasi logika; yaitu teori "atom" (jaubar fard) serta dalil "mumkin dan wajib" yang dikemukakan oleh kelompok Asy'ariyah.

Dalil "jaubad fard"; dalil ini mengatakan bahwa semua benda mengalami pergantian keadaan yang bermacam-macam, baik yang berupa bentuk, warna, gerakan, berkembang, surut, dan perubahan-perubahan lainnya, yang kesemuanya itu disebut "aradb”. Semua benda tersebut dapat dibandingkan terus menerus sampai menjadi bagian terkecil yang tidak bisa dibagi lagi. Bagian terakhir ini disebut dengan "jaubar fard" ("atom"). Kalau atom tidak terlepas dari aradh, sedangkan aradh adalah baru, maka jauhar fard itu baru pula, karena apa yang tidak lepas yang baru adalah baru pula. Tiap yang baru mesti ada yang menjadikan, itulah dia Tuhan. ${ }^{12}$

Maturidy dalam menggunakan dalil jauhar fard ini pada dasarnya sama, hanya gaya pengungkapannya yang berbeda, yaitu: "dalil perlawanan ardh", menurut dia bahwa ala mini tidak mungkin qadim, karena padanya terdapat keadaan yang berlawanan seperti diam dan gerak, baik dan buruk, dan lain-lain. Keadaan tersebut adalah baru dan sesuatu yang tidak terlepas dari yang baru, maka baru pula. "Dalil terbatas dan tidak terbatas" menurut dia alam ini terbatas. Tiap yang terbatas adalah baru. Jadi alam ini adalah baru. ${ }^{13}$

Di samping jauhar fard, juga dalil "mumkin dan wajib” yang diciptakan oleh Juaini (kelompok Asy'ariyah) juga dijadikan sebagai argumentasi untuk membuktikan adanya Tuhan. Dalil ini mengatakan bahwa alam dengan segala isinya bisa terjadi dalam keadaan yang berbeda sama sekali dari pada keadaannya yang sekarang. Matahari misalnya bisa berjalan dari Barat ke Timur. Batu bisa naik ke atas dari pada turun ke bumi. Dengan kata lain alam yang sekarang ini bukan alam yang sebaik-baiknya dan masih terjadi yang lebih baik lagi. Karena tidak ada yang mengharuskan Tuhan memperbuat yang lebih baik. Dengan perkataan lain ala mini adalah yang

${ }^{12}$ A. Hanafi, Theologi Islam (Jakarta: Bulan Bintang, t.th.), h. 84-85.

${ }^{13}$ A. Hanafi, Theologi Islam, h. 89. 
mumkin bisa wujud dan bisa tidak wujud. Akan tetapi kenyataannya alam ini telah menjadi wujud yang nyata. Tentulah ada zat yang menguatkan segi wujud atau tentulah ada yang mewujudkan, itulah Tuhan. ${ }^{14}$

Dalam masalah "zat dan sifat" Tuhan, aliran Muktazilah menenang keras golongan Mutasyabih. Muktazilah hanya menyifati Tuhan dengan "esa" dan "qadim" dan "berbeda dari makhluk". Sifat ini adalah sifat salabi (negatif) karena tidak menambah sesuatu kepada zat Tuhan.

Washil bin Atha (pendiri Muktazilah) tidak mengakui adanya sifatsifat ijaby (positif) bagi-Nya, seperti ilmu, qudrat, dan iradat. Para perkembangan selanjutnya pengikut-pengikut Washil bin 'Atha menetapkan dua sifat pokok, yaitu "ilmu" dan "qudrat", dan kedua sifat ini disamakan dengan zat Tuhan sendiri. ${ }^{15}$

Menurut Asy'ari bahwa sifat-sifat itu ada pada Tuhan. Asy'ari menetapkan sifat bagi Tuhan, karena perbuatan-Nya di samping menunjukkan bahwa dia mengetahui, berkuasa, berkehendak dan lain sebagainya, adalah kenyataan bahwa Ia mempunyai ilmu, kehendak dan berkuasa. Lebih lanjut dijelaskan, Tuhan mutlak mempunyai sifat-sifat, karena perbuatan-Nya, Tuhan berkehendak, berkuasa, mengetahui dan lainlain. Ini berarti Tuhan mempunyai sifat berkehendak, sifat kuasa, sifat ilmu, dan lain-lain. Sifat Tuhan itu menurut Asy'ari bukan zat Tuhan tetapi ia bukan lain dari zat Tuhan. ${ }^{16}$

Masalah sifat Tuhan ini lebih Nampak lagi dikembangkan oleh alSanusi $(1427$ - 1490). Dia mengonstruksikan masalah sifat-sifat itu atas dasar filsafat.

Asy'ariyah yang bercorak Sanusiyah ini sangat disenangi di Indonesia. Dalam masalah ini sangat jelas adanya pembagian sifat-sifat Tuhan, Rasul-rasul-Nya kepada jumlah tertentu dan membaginya ke dalam wajib, mustahil dan jaiz.

Masalah "qadha dan qadar" (perbuatan manusia) pada dasarnya aliran Muktazilah dan Asya'ariyah sama-sama membagi perbuatan manusia menjadi dua bagian.

${ }^{14}$ A. Hanafi, Theologi Islam, h. 87.

${ }^{15}$ A. Hanafi, Theologi Islam, h. 104-105.

${ }^{16}$ M. Laily Mansur, Imam Asy'ari (Surabaya: Bina Ilmu, 1981), h. 33-34. 
Pertama, kedua aliran ini sependapat ada perbuatan yang timbul dengan sendirinya (seperti gerakan refleksi). Perbuatan ini jelas bukan keadaan manusia (terjadi menurut kehendaknya).

Kedua, "perbuatan bebas", menurut Muktazilah perbuatan bebas ini pada dasarnya manusia bisa melakukan pilihan antara mengerjakan dan tidak mengerjakan. Perbuatan semacam ini lebih pantas dikatakan diciptakan manusia dari pada dikatakan diciptakan Tuhan.

Sedangkan menurut Asy'ari dan pengikutnya mengatakan dengan adanya istilah "kasab", yaitu bersamaannya kekuasaan manusia dengan perbuatan Tuhan. Maksudnya apabila seseorang hendak mengadakan suatu perbuatan, maka pada saat itu juga Tuhan menciptakan kesanggupan manusia untuk mewujudkan perbuatan tersebut. Dengan perbuatan inilah ia mendapatkan perbuatannya, tetapi tidak menciptakannya. ${ }^{17}$

Itulah beberapa contoh masalah Ilmu Kalam yang berkembang di masa Abbasyiah dan sekarang menjadi panutan umat Islam di jaman ini, seperti di Indonesia.

\section{Penggunaan SKI dalam Memahami Ilmu Ushuluddin}

Masalah akidah Islam (kepercayaan - keyakinan) yang ada sejak lahirnya sampai pada pertumbuhan selanjutnya - pada dasarnya tidak lepas dari sumbernya, yaitu Alquran dan Hadis. Kedua sumber tersebut telah memberikan dasar-dasar keyakinan dan mengajak kepada umat manusia untuk bertauhid (mengesakan Tuhan) dan melarang mempersekutukan-Nya.

Usaha untuk menanamkan jiwa tauhid (akidah Islam) ini nampaknya dalam perjalanan sejarah sangat bervariasi, terutama pada modus yang mereka terapkan. Bahkan di samping modus yang berbeda ada beberapa hal dalam Alquran dan Hadis dijadikan permasalahan dan pembicaraan yang disangkut pautkan dengan ketuhanan.

Di masa Rasulullah akidah Islam masih dalam bentuk yang murni dan sederhana. Masalahnya tidak keluar dari ketentuan pokok yang sudah digariskan oleh Alquran dan Hadis, meskipun dalam kedua sumber itu ada mengandung ayat-ayat "jabar", "ikhtiar" dan "ayat-ayat mutasyabihat",

\footnotetext{
${ }^{17}$ A. Hanafi, Theologi Islam, h. 168-170.
} 
namun sikap mereka cukup dengan iman tanpa penyelidikan dan perbincangan yang berkepanjangan tanpa ada penyelesaian.

Keadaan akidah Islam pada masa Rasulullah itu cukup sederhana, hal ii dapat kita pahami karena agama Islam adalah agama untuk setiap tingkatan manusia, maka Rasulullah dalam menanamkan akidah Islam dalam fase-fase seruan-seruannya itu cukup dengan mengiktikadkan bahwa "tidak ada tuhan yang disembah selain Allah, yaitu Tuhan yang menciptakan dan mengatur alam dan dia (Muhammad) utusan Allah". Kenyataan ini nampak dalam usaha beliau melaksanakan seruannya, baik seruan orang seorang, seruannya untuk umum, maupun seruannya ke keluarga Bani Abdul Muthalib. Seruannya untuk umum, baik sewaktu masih berada di Mekkah, maupun seruannya di Madinah. Isi seruan beliau selalu mengajak untuk percaya/iman sepenuhnya dengan Tuhan yang esa dan meninggalkan pemujaan kepada berhala. ${ }^{18}$ Apa yang beliau lakukan itu sejalan dengan jiwa Alquran.

Dari kenyataan sejarah itu dapat dipahami lebih lanjut bahwa beliau dalam menanamkan akidah Islam pada umatnya cukup dengan iman, tidak pernah menggunakan dalil-dalil filsafat maupun dalil-dalil ilmiyah lainnya, meskipun di dalam Alquran banyak ayat yang mengajak untuk memperhatikan, memikirkan dan menyelidiki alam sekeliling kita. Lebih dari itu yang jelas Rasulullah sendiri pada waktu itu selalu mencegah ada usaha-usaha untuk memahami dan menakwilkan ayat-ayat mutasyabihat, jabar, dan ayat-ayat ikhtiar sebagaimana diriwayatkan dalam hadis Rasulullah.

Demikian pula di masa Khalifaturrasyidin, pada dasarnya akidah Islam tidak berbeda dengan masa Rasulullah. Hal ini disebabkan sikap para Rasulullah. Di samping itu Islam pada masa ini belum banyak berhadapan dengan kebudayaan bangsa lain. Meskipun pada masa30 tahun $(10-40 \mathrm{H})$ wilayah Iran, Irak, Syiria, Palestina dan Mesir sudah dimasuki Islam.

Dalam masa Daulat Bani Umayyah sudah mulai nampak ada aliran keagamaan seperti Khawarij, Syi'ah, dan Murji'ah yang sebenarnya akibat dari kekacauan politik pada masa Khalifah Ustman bin 'Affan dan Ali bin

\footnotetext{
${ }^{18}$ A. Syalabi, Sejarah dan Kebudayaan Islam (Jakarta: Jaya Murni, 1977), h. 59-74.
} 
Abu Thalib. Meskipun benih-benih pertikaian dalam segi ketuhanan ini (seperti masalah berbuat dosa besar, qadar, dan istitha'ah) sudah ada, akan tetapi tidak subur dalam perkembangannya.

Keadaan ini disebabkan pada masa Daulah Bani Umayyah (41-132 H./661-750 M.) merupakan masa pemerintahan yang sifatnya perluasan wilayah dan pembangunan fisik ke dalam serta stabilitas keamanan. Di masa ini wilayah kekuasaan Islam sampai membentang dari pegunungan Thian Shan di sebelah Timur sampai pegunungan Pyrences di sebelah Barat (seperti daerah Sind di Indian, Afganistan, Asia Kecil, Afrika Utara dan Barat, Kepulauan Sicilia, Spanyol, Portugal, di samping wilayah Iran, Irak, Palestina, Mesir dan Syiria yang sudah dikuasai sejak masa Khalifaturrasyidin. ${ }^{19}$

Sedangkan firkah-firkah keagamaan pada masa ini lebih banyak membuat kerusuhan di beberapa daerah kekuasaan Islam. kegiatan mereka lebih banyak bersifat politis. ${ }^{20}$

Pada masa selanjutnya yaitu masa Daulah Bani Abbasyiah keadaannya sudah agak berbeda, terutama pada masa Khalifah ke VII (al-Mukmun, 198-189 H./813-833 M.). Meskipun sebelumnya, pada masa Khalifah ke III (al-Mahdi, 158-169 H./775-785 M.) sudah mulai kecenderungan untuk mengembangkan filsafat dan ilmiah. Di masa khalifah ini sudah senantiasa dilangsungkan diskusi-diskusi agama dan filsafat. Khalifah sendiri bersikap toleran terhadap berbagai agama dan aliran-aliran filsafat. Sikapnya yang terbuka ini disebabkan usahanya untuk memberantas paham-paham yang bertentangan dengan Islam melalui cara mempelajari agama dan aliran filsafat tertentu. Bahkan dia menganjurkan mengarang buku yang bersifat kontroversial yang bisa membantah paham tersebut.

Namun pada hakikatnya masa sebelum khalifah al-Makmun tidak jauh berbeda dengan masa Daulah Bani Umayyah, yaitu senantiasa menstabilisasikan kerusuhan-kerusuhan yang sering timbul dari dalam sendiri, disamping berulang kali menghadapi kekuasaan Imperium Roma Timur. $^{21}$

\footnotetext{
${ }^{19}$ Yoesoef Sou'yib, Sejarah Daulah Abbasyiah (Jakarta: Bulan Bintang, 1977), h. 7-11.

${ }^{20}$ Yoesoef Sou'yib, Sejarah Daulab Umayyah I (Jakarta: Bulan Bintang, 1977), h. 7.

${ }^{21}$ Yoesoef Sou'yib, Sejarah Daulah Abbasyiah I, h.
} 
Akan tetapi pada masa 10 tahun terakhir dalam kekhalifahan alMakmun merupakan masa penuh keamanan di dalam seluruh wilayah Islam. Tidak pernah bangkit kerusuhan lagi, baik sekta Syi'ah maupun sekta Khawarij.

Karena itu pada masa ini al-Makmun menggalakkan pembangunan, baik di bidang fisik maupun di bidang spiritual. Dalam bidang spiritual alMakmun menyediakan Balai Penghadapan (Balai Pertemuan) untuk ahliahli ilmu, ahli-ahli hukum, ahli-ahli pikir, ahli-ahli agama, ahli-ahli bahasa, ahli-ahli sastra untuk memperbincangkan dan bertukar pikiran di dalam segala macam permasalahan agama. Di samping itu karya-karya Grik yang dibawa dari Konstantinopel segera disalin. Perguruan-perguruan bagi ahli penerjemah dibuka di Bagdad. Sekian banyak perpustakaan didirikan antara lain "Baitul Hikmah" yang terkenal kaya raya dengan naskah.

Di majelis diskusi ini sangat didominasi oleh pemikiran Grik (logika) sebagai alat argumentasi untuk mematahkan setiap pendapat dan keyakinan yang berlawanan dengan kebenaran Islam. Oleh karenanya pemuka-pemuka agama lain dengan sukarela memeluk agama Islam.

Dalam kondisi seperti ini kelompok ahli pikir (aliran iktizal) sangat besar jasanya bagi kepentingan Islam. kelompok ahli pikir ini menurut H.A.R Gibb di dalam karyanya Mohammadanism telah mampu menjembatani jurang perbedaan antara ajaran Islam yang murni dengan kebudayaan Grik dan paham Gostik yang telah berusia tua di Asia Barat.

Karena pertemuan Islam dengan kebudayaan asing itulah yang menjadi pangkal sebab timbulnya bid'ah-bid'ah di abad pertama dan kedua hijriah (terutama di wilayah Irak). Selanjutnya bid'ah dan khurafat dapat diatasi oleh pemuka Iktizal dengan merumuskan keyakinan Islam dalam bentuk baru.

Mengenai keyakinan umat Islam pada masa itu benar-benar menjadi perhatian khalifah al-Makmun. Karena al-Makmun menyadari kedudukannya sebagai Amirul Mukminin merasa kewajibannya untuk memelihara kemurnian agama beserta menegakkan kebenaran (al-haqq) dalam lingkungan masyarakat. Kesadarannya itu timbul ketika dia beristirahat di wilayah Kilikia (Asia Kecil) yaitu tempat kelahiran Paulus yang dianggap Rasul utama oleh dunia Kristen dan yang merumuskan pokok-pokok keyakinan yang menjadi anutan dunia Kristen. 
Di Kilikia ini al-Makmun menyaksikan pengertian "Yesus itu Kalam Allah" dengan tafsiran yang keliru, yaitu penafsiran yang jauh menyimpang dari pengertian keesaan Ilahi. Dari situ dia bangkit untuk menghindari adanya penafsiran umat Islam mengenai Alquran itu Kalam Allah.

Persoalan ini mengakibatkan al-Makmun menggunakan kekuasaannya untuk memanggil dan menahan orang yang mengiktikadkan bahwa Alquran itu qadim. Sebab menurut dia keyakinan seperti itu syirik. Beranjak dari persoalan itulah yang merupakan bagian dari thesis aliran Iktizal tentang keesaan Ilahi. Dari sinilah masalah "zat dan sifat", serta "wujud Tuhan" dan sebagainya, menjadi objek pembicaraan dari aliran Muktazilah, Asy'ariah, Maturidiyah serta kelompok-kelompok yang ada dalam suatu aliran di kemudian hari.

Dapat diperhatikan kenapa masalah "zat dan sifat" Tuhan pada masa Abbasyiah menjadi perbincangan yang tajam, apakah sifat zat dan sifat fi'il. Masalah ini ditimbul dimulai dari al-Makmun yang beraliran Aktizal khawatir apabila Kalam Allah (Alquran) itu disifati dengan qadim akan menjadikan adanya dua yang qadim. Hal ini menurutnya membawa kesyirikan, sebagaimana terjadi dalam dunia Kristen tentang tiga oknum yang berdiri sendiri. Dalam hal ini mereka berpendapat bahwa sifat kalam dan sifat-sifat Tuhan lainnya itu adalah zat Tuhan sendiri. Pengertian ini menurut mereka tidak akan menimbulkan bilangan pada zat Tuhan. Pemikiran ini menurut A. Hanafi dalam bukunya Theologi Islam halaman 39-40 telah terpengaruh dengan golongan Nastoria (suatu kelompok dalam dunia Kristen) yang berpendapat bahwa "Allah", "Kalimat Allah" dan "Roh Kudus" adalah satu hakikat (hakikat wujud). Selanjurnya dijelaskan bahwa pemikiran tersebut diduga terpengaruh dengan Neo Platonisme yang mempercayai "Sumber Alam" atau "Keesaan Tuhan".

Demikian pula dengan argumentasi mutakallimin tentang wujud (Tuhan) dengan menggunakan dali jaubad fard (teori atom). Teori ini mengatakan bahwa adanya alam yang baru ini membutuhkan adanya yang menciptakan, yaitu wujud yang pertama (wujud mutlak). Menurut A. Hanafi (Theologi Islam) halaman 37, "membicarakan tentang wujud mutlak adalah pembicaraan filsafat".

Dari sisi ini dapat dipahami dan disimpulkan bahwa masalah-masalah ilmu kalam yang timbul pada masa mutakallimin di masa Bani Abbasyiah 
ini disebabkan masyarakat Islam pada masa itu menghadapi pemikiranpemikiran filsafat dan agama-agama lain yang juga sudah terpengaruh dengan filsafat. Sehingga pemikiran-pemikiran Islam (mutakallimin) berusaha membendung kemurnian akidah Islam dengan cara memperbincangkan hal-hal yang bisa membuat umat Islam terpengaruh dengan pemikiran filsafat dan aliran-aliran agama yang sesat. Argumentasinya pun mereka gunakan dengan argumentasi filsafat. Hal ini dapat dipahami bahwa karena pada masa itu pengaruh dari luar (filsafat dan aliran agama) didominir oleh pemikiran filsafat dan logika mendapat perhatian dan disenangi oleh umat Islam pada masa itu.

Terlepas dari sikap menilai "benar tidaknya" aliran-aliran ilmu kalam itu atau aliran-aliran mana yang benar, namun yang jelas semuanya itu adalah usaha pemikiran yang mereka sumbangkan untuk menjawab tantangan jamannya, dan tentu bermanfaat bagi masyarakat dan masa itu.

Keadaan akidah Islam pada masa mutakkalimin yang berbeda coraknya dengan jaman Rasulullah dan jaman sahabat itu tidak bisa lepas dari perubahan masyarakat (proses sosial), yaitu tidak lepas dari suatu kenyataan yang mempunyai kesatuan dengan waktu, tempat, kebudayaan, golongan dan lingkungan dimana aliran-aliran itu tumbuh.

Karena itu Ilmu Tauhid (Ilmu Kalam) yang ada sekarang ini merupakan produk pemikiran ulama-ulama abad silam, maka yang perlu kita lakukan adalah "kenapa mutakallimin melakukan seperti itu". Yang jelas berdasarkan analisa terdahulu, bahwa pembincaraan masalah ketuhanan pada masa itu dengan pendekatan filsafat adalah karena kondisi dan situasinya yang menuntut.

Dengan tidak mengesampingkan apa yang telah dibicarakan oleh tokoh-tokoh/pemikir-pemikir agama di masa lampu dengan cara dan kemampuannya, serta telah diperpegangi oleh pengikutnya, kami berkesimpulan bahwa ilmu tauhid yang ada selama ini memang berhasil bertahan sebagai kategori logika.

Pendekatan dengan kategori logika senantiasa menyangkut proses obyektivikasi, dalam mana Tuhan lalu menjadi objek kajian, terlepas dari hubungannya dengan manusia. Oleh karena itu kita mungkin memerlukan suatu modus ilmu tauhid yang lebih fungsional, sebab hubungan kita dengan Tuhan bisa dihayati, bukan hanya dimengerti atau diyakini. Untuk jaman 
kita sekarang, dimana jaman pengetahuan dan teknologi sangat membantu dalam dunia pembangunan, dirasa perlu Ilmu Tauhid yang relevan untuk dikembangkan. Memperhatikan benda-benda alam ini dengan seksama (melalui metode ilmu) akan menghasilkan hasil ganda, yaitu di samping kita akan kagum dan menyadari akan adanya Zat Tuhan Maha Mengatur, juga sekaligus dari hasil penelusuran terhadap benda-benda ala mini akan memberi manfaat besar dalam memenuhi keperluan hidup.

\section{Penutup}

Dari uraian-uraian di atas dapat penulis simpulkan bahwa Ajaran Islam mengandung kebenaran dan keselamatan yang pokok-pokok ajarannya terdapat dalam Alquran dan Hadis itu harus diyakini dan dihayati akan kebenarannya. Baik dalam bidang syari'at maupun akidah.

Islam lahir dan berkembang tidak lepas dari proses kesejarahan. Oleh karena itu untuk memahami agama Islam juga diperlukan suatu pendekatan yang bersifat sosio-historis.

Demikian halnya dengan ilmu Ushuluddin dari awal kelahirannya dan perkembangan selanjutnya juga diwarnai oleh pemikiran-pemikiran umat Islam dalam bidang itu yang mana pemikiran-pemikiran tersebut sangat dipengaruhi oleh faktor-faktor situasional dan kondisional pada jamannya.

Berdasarkan pemikiran pada poin 1, 2, dan 3, maka di sini berusaha untuk mengungkapkan bahwa SKI yang merupakan bagian dari sosiohistoris, dapat dijadikan sebagai alat untuk memahami ajaran Islam dengan memperhatikan socio cultural dimana ia tumbuh dan berkembang. Lebih khusus lagi bahwa untuk memahami Ilmu Ushuluddin disepanjang sejarah sangat diperlukan pendekatan sosio historis (SKI).

Perkembangan Ilmu Ushuluddin dari jaman Rasulullah, masa Khalifaturrasyidin, Bani Umayyah, Bani Abbasyiah dan seterusnya, mempunyai kekhususan-kekhususan tersendiri. Hal tersebut dikarenakan adanya hubungan timbal balik tempat, waktu, situasional, kondisional pada saatnya.

SKI yang merupakan salah satu mata kuliah di Ushuluddin bisa berdaya guna untuk mempertajam pemahaman terhadap Ilmu Ushuluddin dengan memakai kacamata SKI. 
Dengan melihat perkembangan Ilmu Ushuluddin dari masa ke masa, maka bisa ditarik kesimpulan bahwa buah pikiran ulama terdahulu itu mampu menjawab tantangan yang pada waktu itu. Ini berarti bahwa di jaman abad sekarang dimana pengetahuan dan teknologi berkembang dengan pesat dirasa perlu Ilmu Tauhid model baru yang sesuai dengan situasi dan kondisi saat ini. Ayat-ayat kauniah yang banyak terdapat dalam Alquran perlu dipelajari secara khusus, hal ini telah dirintis oleh Bapak filsafat Ibnu Rusyd []

\section{DAFTAR PUSTAKA}

Abdul Muin, M. T.T. Imu Kalam. Jakarta: Wijaya, 1973.

Amin, Ahmad. Fajr al-Islam, terj. Zaini Dahlan. Jakarta: Bulan Bintang, 1968.

Baunu, Gregory. Agama dalam Bayang-bayang Relativisme. Yogyakarta: Tiara Wacana, 1999.

Hanafi, A. Theologi Islam. Jakarta: Bulan Bintang, t.th.

Kusumo, Hilman Hadi. Antropologi Agama Bagian I. Bandung: PT. Citra Aditiya Bakdi, 1993.

Mansur, M. Laily. Imam Asy'ari. Surabaya: Bina Ilmu, 1981.

Mauhein, Karl. Ideology and Utopia (Havert Book). New York: Haurecaunt Brace \& Word, 1936.

Mustafa al-Garaby, Ali. Tarikh al-Firaq al-Islamiy. t.tp.: Azhar, t.th.

Nasution, Harun. Islam Ditinjau dari Beberapa Aspek. Jakarta: Bulan Bintang, 1974.

Shiddieqy ash-, Hasby. Sejarah Pengantar Ilmu Taubid. Jakarta: Bulan Bintang, 1979.

Sou'yib, Yoesoef. Sejarah Daulah Abbasyiah. Jakarta: Bulan Bintang, 1977.

—_, Sejarah Daulah Umayyah I. Jakarta: Bulan Bintang, 1977.

Syalabi, A. Sejarah dan Kebudayaan Islam. Jakarta: Jaya Murni, 1977. 